\title{
Formation of Readiness of Future Teachers of Physical Education for Animation Activity in Secondary Schools of Ukraine
}

\author{
Volodymyr Naumchuk ${ }^{1, *}$, Anna Sydoruk ${ }^{2}$, Natalia Makovetska ${ }^{2}$ \\ ${ }^{1}$ Department of Theoretical Foundations and Methods of Physical Education, Ternopil Volodymyr Hnatiuk National Pedagogical \\ University, 46027, Ternopil, Ukraine \\ ${ }^{2}$ Department of Tourism and Hotel and Restaurant Business, Zaporizhzhia National University, 69600, Zaporizhzhia, Ukraine
}

Received September 14, 2020; Revised November 10, 2020; Accepted November 29, 2020

\section{Cite This Paper in the following Citation Styles}

(a): [1] Volodymyr Naumchuk, Anna Sydoruk, Natalia Makovetska , "Formation of Readiness of Future Teachers of Physical Education for Animation Activity in Secondary Schools of Ukraine," International Journal of Human Movement and Sports Sciences, Vol. 8, No. 6, pp. 403 - 412, 2020. DOI: 10.13189/saj.2020.080612.

(b): Volodymyr Naumchuk, Anna Sydoruk, Natalia Makovetska (2020). Formation of Readiness of Future Teachers of Physical Education for Animation Activity in Secondary Schools of Ukraine. International Journal of Human Movement and Sports Sciences, 8(6), 403 - 412. DOI: 10.13189/saj.2020.080612.

Copyright $@ 2020$ by authors, all rights reserved. Authors agree that this article remains permanently open access under the terms of the Creative Commons Attribution License 4.0 International License

\begin{abstract}
The purpose of the study is to determine the content and organizational and pedagogical conditions of professional training of future teachers of physical education for animation activities in secondary schools and involves the development and experimental testing of the relevant conceptual model. For a physical education teacher, animation is a purposeful activity that provides the formation of a spiritually and physically health, socially active personality of a student capable of self-development and self-improvement in the field of leisure. The structural components of the readiness of future physical education teachers for animation activities, which is considered as a systemic quality of personality, are motivational and target, cognitive and content, activity and creative, and reflexive and evaluative. The effectiveness of professional training of future physical education teachers for animation activities in secondary school is ensured by the implementation of a set of organizational and pedagogical conditions, namely: orientation of the content of pedagogical education of future physical education teachers on the formation of readiness for animation activities; directing the practical training of students to the development of skills in the design and organization of animation activities in a secondary school; formation of students' holistic idea of the essence of animation activities by involving them in the developmental animation
\end{abstract}

educational environment.

Keywords Professional Training, Physical Education Teacher, Animation Activities, Secondary Schools

\section{Introduction}

There are many factors leading to the deterioration of health and physical development of children and youth: the decrease of general culture, decline of healthy lifestyles, increasing types of addictive behavior, significant shortcomings in the organization and methods of physical education, placing additional demands on the quality of training of future physical education teachers. One of the ways to solve these problems and improve the educational process in secondary schools is associated with the development of the educational environment of students, improving their leisure and, in particular, with animation activities [1-3].

The need for proper management of animation activities in secondary schools is determined by the fact that animation is an important component of organized leisure of students - free from compulsory activities [4-7]. It is a personally significant and socially useful area of life 
of students, which contributes to the humanization of education and enables the active assimilation of social and cultural heritage [8]. Animation activities allow a continuous and diverse pedagogical influence on school-age children, thus ensuring the proper solution of the entire system of tasks of their physical education. Based on creativity, this type of activity forms the skills of interaction, develops the ability to respect and appreciate another person, their opinion, allows them to understand and accept something new and unusual [9]. Quality leisure management involves self-knowledge of the world and oneself, the development of skills and abilities to lead a healthy lifestyle, values to one's health [10]. And a healthy young generation is a guarantee of stable development of the state, one of the factors of its positive international image.

The need to form the readiness of future physical education teachers for animation activities in secondary school acknowledges modern society's requirements for the professional activities of teachers of this profile, which should provide appropriate conditions for comprehensive and harmonious development of the student's personality, including the use of innovative interactive, game technologies and implementation of various animation activities [2,11,12]. In addition, this aspect of the training of physical education teachers largely determines the quality of cultural, educational, physical educational and sportive, health and recreation and management aspects of their work $[13,14]$.

However, the analysis of curricula of higher educational institutions of Ukraine shows that animation activities in the process of training future physical education teachers are not given enough attention. This is manifested in the absence of special disciplines and the necessary practice to ensure the formation of appropriate readiness [15]. The content of animation activities, forms and methods of its teaching are not considered as components of a holistic system. The effectiveness of preparing students for animation activities is reduced due to insufficient organizational and pedagogical conditions [16]. This gives grounds to claim that domestic education not only does not properly use the functionality of the animation phenomenon [9], but also does not provide in Ukraine a full and purposeful training of animators of any profile [10].

We see the solution to this problem in creating a system of professional training of future physical education teachers for animation activities, which would ensure the proper formation of the necessary professional and pedagogical competencies, would allow a graduate to enter the labor market being better prepared, would reduce the period of their adaptation to work at school. The professional training of physical education teachers requires a clear focus on the model, which should not only meet the needs of the school, but also be ahead of them. It is necessary to anticipate the results of training future professionals as competent, professionally ready to work not in five or six years, after graduation, but at least 10-15 years ahead, taking into consideration the development of society and the teaching profession [17].

\section{Objectives}

The objectives of this article are to present the results of our experimental work related to the formation of future teachers of physical culture readiness for animation activities in secondary schools of Ukraine. In our research, we sought to find answers to the following questions:

I. What are the characteristics of the essence of animation?

II. What components determine the structure of the future physical education teacher's readiness for animation activities?

III. What complex of organizational and pedagogical conditions will ensure the effectiveness of the process of forming the readiness of future physical education teachers for animation activities?

At the same time, this article presents a conceptual model of training future physical education teachers for animation activities in secondary schools of Ukraine.

\section{Materials and Methods}

The research was conducted on the basis of two higher educational institutions of Ukraine. The pedagogical experiment involved 326 university students and 35 lecturers, as well as 198 secondary school students and 51 physical education teachers.

Theoretical bases of formation of readiness of future teachers of physical education for animation activity were studied by means of the analysis, synthesis, generalization and comparison of the scientific information on a research problem, educational and methodical and normative documentation; modeling of professional training of future physical education teachers for animation activities; comparison of the obtained experimental data.

To form the readiness of future teachers of physical education for animation activities and to test the effectiveness of organizational and pedagogical conditions that ensure the effectiveness of this educational process, a pedagogical experiment was used, supplemented by the necessary observations.

Determination of the complex indicator (CIAA) of the levels of readiness of future teachers for animation activities in secondary school was carried out according to the method by Danylenko [18], which was modified to our study (Table 1). 
Table 1. Technology of calculation of the complex indicator of levels of formation of readiness of future teachers for animation activity in secondary school

\begin{tabular}{|c|c|c|}
\hline Components & Criteria & Diagnostic tools \\
\hline $\begin{array}{l}\text { Motivational and target } \\
\text { MT } \\
\qquad T=\frac{\sum_{i=1}^{n} V_{i}}{n}\end{array}$ & Value (V) & $\begin{array}{l}\text { 1. Methods of studying the need to achieve the goal (V1) } \\
\text { 2. Questionnaire "Motivation for animation activities" (V2) } \\
\text { 3. Questionnaire "Value orientations in the field of leisure and } \\
\text { animation" (V3) }\end{array}$ \\
\hline $\begin{array}{c}\text { Cognitive and content } \\
\text { CS } \\
C S=\frac{\sum_{i=1}^{n} O_{i}}{n}\end{array}$ & Operational (O) & $\begin{array}{l}\text { 1. Diagnosing future professionals on the level of mastering the } \\
\text { basic concepts in the field of animation (O1) } \\
\text { 2. Diagnosing future professionals on the level of mastering the } \\
\text { main aspects of the organization of animation activities (O2) } \\
\text { 3. Map of self-analysis of knowledge and skills on the basics of } \\
\text { animation (O3) }\end{array}$ \\
\hline $\begin{array}{l}\text { Activity and creativity } \\
\text { AC } \\
A C=\frac{\sum_{i=1}^{n} P_{i}}{n}\end{array}$ & Personal (P) & $\begin{array}{l}\text { 1. Methods of self-diagnosis of persistence (P1) } \\
\text { 2. Questionnaire "Predisposition to animation activities" (P2) } \\
\text { 3. Questionnaire "Study of communicative (P3) and organizational } \\
\text { skills" (P4) }\end{array}$ \\
\hline $\begin{array}{l}\text { Reflexive and evaluative } \\
\text { RE } \\
R E=\frac{\sum_{i=1}^{n} R_{i}}{n}\end{array}$ & Resultative (R) & $\begin{array}{l}\text { 1. Methods for determining levels of self-evaluation (R1) } \\
\text { 2. Methods for determining levels of subjective control (R2) } \\
\text { 3. Methods of determining levels of } \\
\text { self-management (R3) }\end{array}$ \\
\hline \multicolumn{3}{|c|}{$\mathrm{CIAA}=\frac{\mathrm{MT}+\mathrm{CS}+\mathrm{AC}+\mathrm{RE}}{4}$} \\
\hline
\end{tabular}

Pearson's non-parametric "chi-square" criterion was used to assess the qualitative growth of the level of readiness of future physical education teachers for animation activities in secondary school. Pearson's criterion was determined by formula (1):

$$
\chi^{2}=\sum \frac{\left(f-f^{\prime}\right)^{2}}{f^{\prime}} \text {, where }
$$

$\chi^{2}-$ Pearson's criterion;

$f$ - actual distribution frequencies;

$f^{\prime}$ - expected distribution frequencies.

The obtained value $\chi^{2}$ was compared with the tabular one, the value of which was chosen according to the degree of freedom and the level of significance [19].

\section{Results}

\subsection{The Essence and Characteristics of Animation Activities}

In the scientific literature, one can find different definitions of the concept of "animation", the basis of which is determined by the Latin word 'anima' - the soul. In particular, animation is considered as: the formula of "three D": 'delassiment' (relaxation), 'divertissement' (entertainment) and 'develop-pement’ (development) [20]; part of the cultural and educational system of society [21]; stimulating full-fledged recreational, social and cultural, educational, cultural and leisure activities of the human [22]; organized process of entertainment and exercise, which provides motor activity and communication [23]; stimulating human vitality by involving it in activity [24]. In UNESCO, social and cultural animation is interpreted as a set of social and cultural practices aimed at stimulating initiative, as well as the participation of individuals in the process of their own development and the global dynamics of social and political life in which they are integrated [25].

Animation, as a professional activity of a physical education teacher, is a complex pedagogical process aimed at creating optimal conditions for learning, education and development (self-development) of the student's personality, choosing opportunities for creative self-expression and self-realization. The essence of animation activity is the organized interaction of its participants in the field of leisure, which allows the formation of spiritually and physically healthy personality, meeting their various interests and needs. With its help, the student masters the surrounding reality and prepares for its transformation. Animation activity removes from amorphousness, allows to turn possible into real, increases the level of freedom, expands the functions of leisure, enriches the meaning of life itself.

In its space, animation helps to adapt the process of 
cognition to the individual characteristics of the student, provides a situation of success, an atmosphere of comfort, establishes the psychosomatic balance of personality. The synthesis of animation and educational activities allows the transformation of external experience of knowledge into internal, the transition from abstract to concrete, ideal to real, which allows to give the developmental and cognitive process a more independent character. Thus activity of the student acts as one of psychological and pedagogical mechanisms of mental, social, moral, physical, emotional growth of the person, their entering the culture.

On the one hand, the concept of "animation" emphasizes the spiritual aspect of the relationship among the subjects of the pedagogical process, and on the other involves active cognitive activity of humanistic, cultural and health orientation. Among the characteristic features that reveal the essence of animation activities, we consider the following:

- voluntariness and initiative - allow conscious self-realization of the student's personality in free time from compulsory activities;

- personal and collective significance - contribute to the creative solution of pedagogical tasks and meet the various needs of the individual and society;

- communicativeness - provides interaction and communication;

- diversity, emotionality and entertainment - allow one to actively stimulate students' motivation;

- complexity and versatility - improve the relationship of theory and practice, provide simultaneous influence on the psychophysiological and motor areas of the student;

- informativeness and representativeness - expand students' worldview, their life experience;

- originality and uniqueness - take into account the interests of each student, national, ethnic and regional characteristics and traditions.

RQ1 Characteristic features that reveal the essence of animation are: voluntariness and initiative, personal and collective significance, communicativeness, diversity, emotionality and entertainment, complexity and versatility, informativeness and representativeness, originality and uniqueness.

Finding out the essential characteristics and content loads of animation activity allows to make better use of its potential opportunities for solving professional and pedagogical tasks. In the context of university education, this makes it possible to purposefully influence both each of the components of the structure of the readiness of future physical education teachers for animation activities, and their preparation for the profession as a whole.

\subsection{The Structure of the Readiness of the Future Physical Education Teacher for Animation Activities}

In our study, we proceed from the fact that the readiness of future physical education teachers to animation activities in secondary school is an integrative state of personality, its systemic quality, which determines the success of preparation, organization and conduct of animation activities in the educational process. This formulation is based on the analysis of works devoted to the study of scientific approaches to understanding the essence of a person's readiness for pedagogical activity functional, personal and integrative [26-28]. In addition, the study of the content and structure of readiness of future physical education teachers took into account the peculiarities of professional activity of teachers of this profile, which are primarily related to solving specific professional and pedagogical tasks: forming students' necessary knowledge and motivation for physical and spiritual improvement, strengthening health, development of motor skills, education of physical and personal qualities, increasing the functional capabilities of the body and others $[2,13,29]$. An important and integral part of the process of determining the structure of readiness of future physical education teachers for animation is the direct study of the content, requirements and direction of the actual animation $[6,11,30]$. Thus, in the structure of the studied readiness, four interrelated and interdependent components were identified (Fig. 1).

RQ2 The structure of readiness of the future teacher of physical education for animation activity is determined by the following components: motivational and target, cognitive and content, activity and creativity and reflexive and evaluative.

The content of the motivational and target component is determined by the acceptance by future professionals of the goals and objectives of animation activities, a steady interest in its implementation, the desire to increase the level of professional readiness in the field of animation, motivation for professional self-development. 


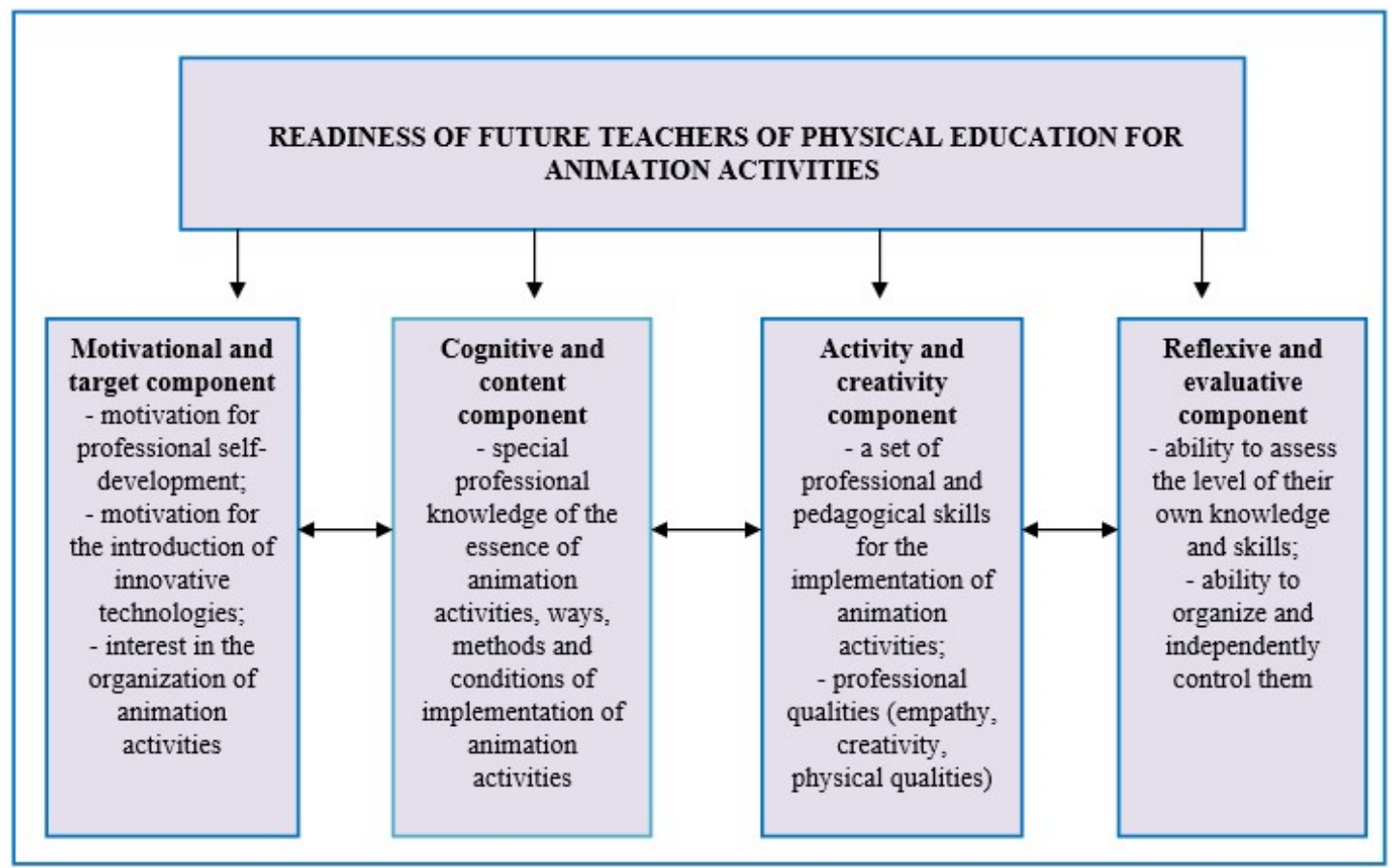

Figure 1. The structure of the readiness of the future physical education teacher for animation activities

The cognitive and content component is represented by a set of professional knowledge on the peculiarities of the organization of animation activities in secondary school, namely: its structural components; ways of implementation, methods and ways of organization in the educational process; conditions that ensure its effectiveness; requirements for the teacher-animator. The content of the activity and creativity component includes a set of professional and pedagogical skills for the implementation of animation activities, in particular: the ability to design animation programs of various orientations and implement them in the educational process; organizational and communication skills; professional qualities that ensure the successful implementation of animation activities, physical abilities, etc. The reflexive and evaluative component includes: the ability of future specialists to assess the level of their own knowledge and skills in the organization of animation activities; ability to independently organize and control the process of knowledge acquisition and their implementation in the practical area.

\subsection{Experimental Verification of the Effectiveness of Professional Training of Future Physical Education Teachers for Animation Activities in Secondary School}

To establish the compliance of the results of professional training of future physical education teachers with the requirements for their knowledge and skills (competencies) in the field of animation activities in secondary school, criteria and indicators were identified that correspond to each component of readiness (Table 2).
Table 2. Criteria and indicators of readiness of the future teacher of physical education for animation activity

\begin{tabular}{|c|c|c|}
\hline Components & Criteria & Indicators \\
\hline $\begin{array}{l}\text { Motivational } \\
\text { and target }\end{array}$ & Value & $\begin{array}{l}\text { Presence of interest in animation } \\
\text { activities; awareness of the } \\
\text { importance of introducing } \\
\text { innovative technologies in the } \\
\text { educational process; striving for } \\
\text { self-development and raising the } \\
\text { level of pedagogical competence } \\
\text { in the field of animation }\end{array}$ \\
\hline $\begin{array}{c}\text { Cognitive and } \\
\text { content }\end{array}$ & Operational & $\begin{array}{l}\text { Availability of special } \\
\text { professional knowledge on: } \\
\text { characteristic features of } \\
\text { animation activity; methods and } \\
\text { ways of its organization; } \\
\text { development of various forms of } \\
\text { animation activities in secondary } \\
\text { school, taking into account the } \\
\text { age and individual psychological } \\
\text { characteristics of students }\end{array}$ \\
\hline $\begin{array}{l}\text { Activity and } \\
\text { creativity }\end{array}$ & Personal & $\begin{array}{c}\text { Availability of a set of } \\
\text { professional and pedagogical } \\
\text { skills for the implementation of } \\
\text { animation activities; ability to } \\
\text { design animation programs of } \\
\text { different orientations and } \\
\text { implement them in the } \\
\text { educational process of } \\
\text { schoolchildren; organizational } \\
\text { and communication skills, } \\
\text { physical qualities, as well as } \\
\text { creativity and empathy }\end{array}$ \\
\hline $\begin{array}{c}\text { Reflexive and } \\
\text { evaluative }\end{array}$ & Resultative & $\begin{array}{c}\text { Ability to self-analysis, } \\
\text { self-organization, reflection }\end{array}$ \\
\hline
\end{tabular}


Table 3. Dynamics of levels of formation of readiness of future teachers of physical education for animation activity (on a complex indicator)

\begin{tabular}{|c|c|c|c|c|c|c|c|c|}
\hline \multirow{2}{*}{$\begin{array}{c}\text { The level of readines } \\
\text { on complex indicator } \\
\text { (CIAA) }\end{array}$} & \multicolumn{4}{|c|}{ Experimental groups (EG) } & \multicolumn{4}{c|}{ Control groups (CG) } \\
\cline { 2 - 10 } & \multicolumn{2}{|c|}{ Actual frequency, $f$} & Theoretical frequency, $f$ & \multicolumn{2}{|c|}{ Actual frequency, $f$} & \multicolumn{2}{c|}{ Theoretical frequency, $f^{\prime}$} \\
\cline { 2 - 10 } & assertion & control & assertion & control & assertion & control & assertion & control \\
\hline Low & 27 & 6 & 24,55 & 9,00 & 33 & 16 & 31,70 & 13,00 \\
\hline Medium & 25 & 15 & 26,18 & 21,68 & 39 & 38 & 41,92 & 31,32 \\
\hline Sufficient & 7 & 23 & 8,59 & 21,27 & 14 & 29 & 11,76 & 30,73 \\
\hline High & 4 & 19 & 3,68 & 11,05 & 5 & 8 & 5,62 & 15,95 \\
\hline
\end{tabular}

The choice of value, operational, personal and performance criteria was made on the basis of the application of the indicator of validity of information, the essence of which is that the information obtained can be trusted only if it is adequate to the object of measurement. These criteria reflect the theoretical level of description of the readiness of future physical education teachers for animation activities. At the same time, the answers received during the experiment of respondents are specific. The transition from the abstract level to concrete observations is carried out with the help of empirical indicators that ensure the operationalization of theoretical concepts. It is the empirical indicator that is an indicator of the criteria being measured [31,32]. This leads to an understanding of the indicator as a quantitative or qualitative characteristic of a criterion of readiness.

Determining the levels of readiness of future physical education specialists for animation activities in secondary school was carried out on the basis of a complex indicator, the use of which allowed to generalize the distribution of students at high, sufficient, medium and low levels. According to the results of the secondary diagnostics of the levels of readiness of future physical education teachers for animation activities, data were obtained that indicate significant positive dynamics by all criteria (Table 3).

The statistically significant difference between the complex indicators of readiness for animation activities of students of experimental groups before and after the implementation of formative measures $\left(x^{2}=34.18\right)$, as well as students of control and experimental groups $\left(x^{2}=\right.$ 15.11) showed their effectiveness and feasibility.

\section{Discussion}

The formation of the readiness of future physical education teachers for animation activities was carried out on the basis of the developed conceptual model, which is presented by a set of components and connections among them, which determine the content structure of this pedagogical process. The experimental model consists of the following blocks: 1) target, which contains the purpose and objectives of the educational process; 2) content, which determines the principles, organizational and pedagogical conditions, forms and methods of training; 3) resultative, which reflects the criteria and levels of efficiency of the educational process (Fig. 2).

According to the presented model, the purpose of professional training of future physical education teachers is oriented and directly reflects the result of this complex and long-term process - the readiness of university graduates for animation activities in secondary school. The training tasks specify the purpose and match the components of readiness of future physical education teachers for animation activities, namely: formation of motivation for professional self-development, for the introduction of innovative technologies, as well as interest in the organization of animation activities (motivational and target component), mastering special professional knowledge about the essence of animation activities, ways, methods and conditions of animation activities (cognitive and content component) professional and pedagogical skills in the implementation of animation activities, the development of professional and personal qualities (activity and creativity component), the formation and development of the ability to assess their own knowledge and skills, the ability to organize and independently control them (reflexive and evaluative component).

The planned result provides for a consistent qualitative transformation of the future teacher's personality, the gradual achievement of the appropriate level of professional and pedagogical competence.

The main principles of readiness of future physical education teachers for animation activities in secondary school, in addition to general pedagogical, are defined as: purposefulness, scientificity, unity of formation of components of readiness, systematicity, consistency, interactivity, contextuality, concentration, consciousness, reflexion and actuality of results. 


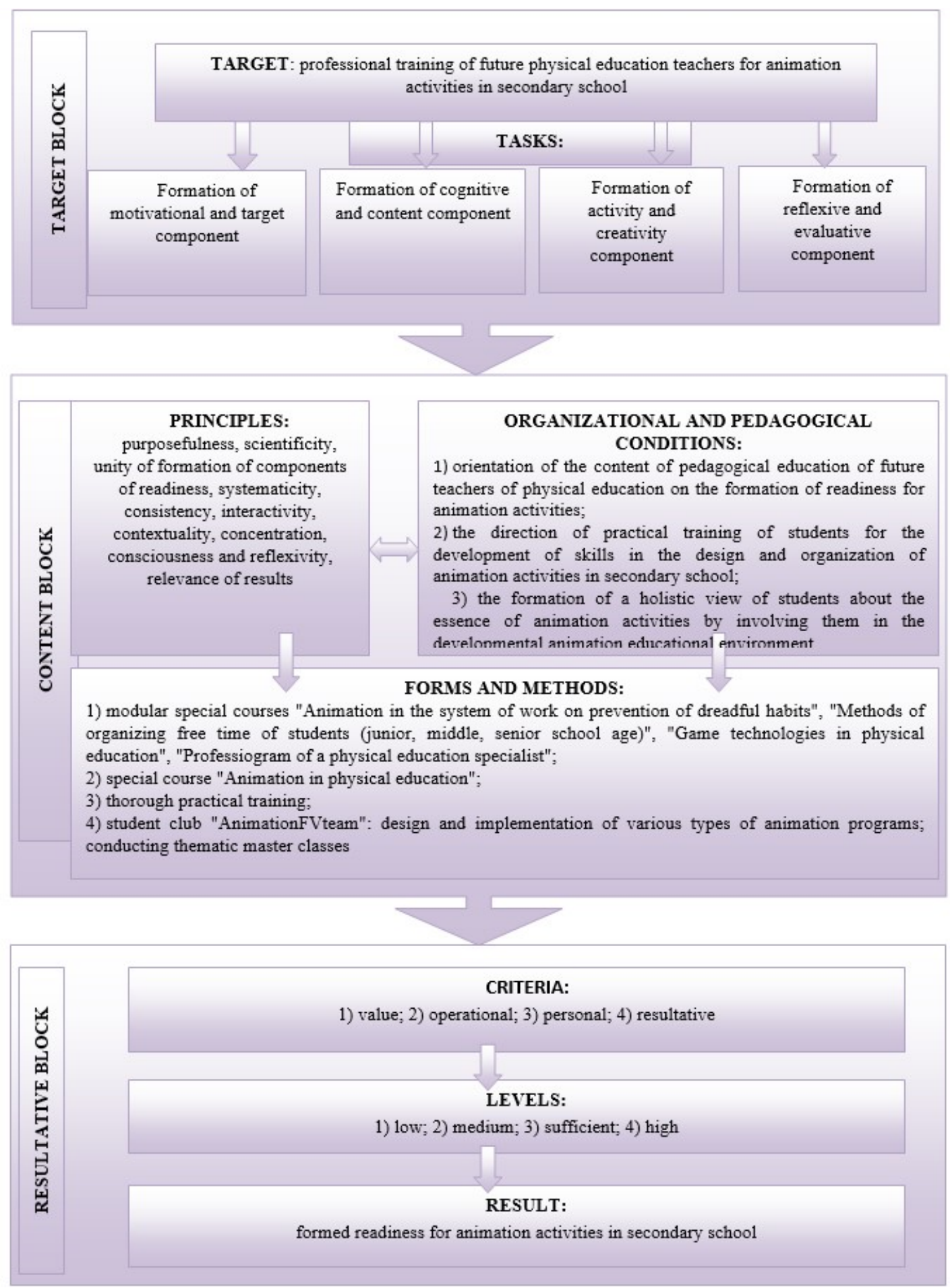

Figure 2. Conceptual model of preparation of future physical education teachers for animation activities in secondary school

Development of an experimental model of training future teachers of physical education for animation activities in secondary school required the definition and justification of organizational and pedagogical conditions that ensure the effectiveness of this process. In this case, the organizational and pedagogical conditions are considered as a result of joint actions of participants in the educational process to achieve the goals and objectives of training and the factors influencing its effectiveness $[17,26]$. Our research gives grounds to determine such organizational and pedagogical conditions for the formation of components of readiness for animation activities, as:

a). orientation of the content of pedagogical training of future physical education teachers on the formation of their readiness for animation activities, which 
provides for its construction in accordance with the content of professional activities and requirements for animators, taking into account the following provisions: structure, logical sequence, scientificity, continuity, practical significance, providing opportunities for general cultural and professional development of personality, individualization and differentiation of education;

b). the direction of practical training of students for the development of skills in designing and organizing animation activities in secondary school, which is achieved by establishing new professionally oriented tasks of introductory, educational and internship practices, the solution of which is ensured by the following principles: continuity and consistency, conscious perspective, increasing difficulties, combination of pedagogical guidance with the development of independence, activity, initiative of students, individual approach, feedback, pedagogical support;

c). formation of students' holistic idea of the essence of animation activity by their involvement in the developmental animation educational environment a qualitative set of conditions for professional training and development of future physical education teachers, providing: recognition of the priority of self-worth of subjects of educational process, shifting the emphasis on the student's independent activity in the design and implementation of animation activities, taking into account the subjective experience of animation activities of the student, purposeful organization of communicative activity, interpersonal communication, etc.

RQ3 The effectiveness of the process of forming the readiness of future physical education teachers for animation activities will provide a set of such organizational and pedagogical conditions: orientation of the content of pedagogical education of future teachers of physical education on the formation of readiness for animation activities, the direction of practical training of students for the development of skills and abilities in the design and organization of animation activities in secondary school, formation of students' holistic idea of the essence of animation activities by involving them in the developmental animation educational environment.

To implement certain organizational and pedagogical conditions in the process of professional training of future teachers of physical culture, we introduced specially organized forms and methods.

Thus, the first condition was fulfilled due to: end-to-end introduction of modular special courses "Animation in the system of work on prevention of dreadful habits", "Methods of organizing free time of students", "Game technologies in physical activity", which contain lectures, practical classes and seminars, materials for independent work of students; introduction of a separate special course "Animation in physical education", which includes lectures and practical classes, performance of individual research task "Portfolio of the future teacher of physical education".

The implementation of the second organizational and pedagogical condition was provided for the introduction of such forms of work in the process of practical training of future teachers of physical education, as: the creation of an animation-oriented project according to a certain scheme; development of the scenario of the animated event; preparation and holding of animation activities in class and extracurricular time; performing self-analysis of lessons and animation activities; organization of group work "From student to teacher"; preparation of a report for the administration and teaching staff of the secondary school on the topic "Features of the methodology of animation activities during the excursion."

Ensuring the third condition required the participation of students in group work on: the organization of animation activities in higher education for moral and spiritual, patriotic and aesthetic education of future teachers; organization of city holidays; promotion of a healthy lifestyle and prevention of socially dangerous diseases among student youth; development of creative abilities of future teachers of physical education, as well as their participation in various thematic master classes on the latest technologies of animation.

\section{Conclusions}

In the professional activity of a physical education teacher, animation activity acts as a conscious, purposeful activity, the purpose of which is to create conditions for the formation of a spiritually and physically healthy, socially active personality capable of self-actualization, self-development and self-improvement in leisure. Characteristic features that reveal the essence of animation activities are: voluntariness and initiative; personal and collective significance; communicativeness; diversity, emotionality and entertainment; complexity and versatility; informativeness and representativeness; originality and uniqueness.

The readiness of future physical education teachers for animation activities in secondary school is considered as an integrative state of personality, its systemic quality, which determines the success of preparation, organization and conduct of animation activities in the educational process. The structure of this readiness is determined by the following components: motivational and target (stimulating interest and motivation of students to animation activities); cognitive and content (formation of knowledge, skills and abilities in the organization of animation activities); activity and creativity (presence of a complex of professional and pedagogical skills on 
realization of animation activity); reflexive and evaluative (ability to put into practice the acquired knowledge and acquired skills).

The effectiveness of the process of forming the readiness of future teachers for animation activities in secondary school is ensured by the implementation of such organizational and pedagogical conditions as:

- orientation of the content of pedagogical education of future teachers of physical education on the formation of readiness for animation activities;

- the direction of practical training of students for the development of skills and abilities in the design and organization of animation activities in secondary school;

- formation of students' holistic idea of the essence of animation activities by involving them in the developmental animation educational environment.

The model includes three interrelated blocks: the target, which contains the purpose and objectives of the educational process; content, which determines the principles, organizational and pedagogical conditions, forms and methods of training; resultative, which reflects the result of the educational process - the readiness of university graduates for animation activities in secondary school, as well as the criteria and levels of its formation. The theoretical validity and practical effectiveness of the proposed model are experimentally proven, as evidenced, in particular, by the comparison of complex indicators of readiness for animation activities of students of control and experimental groups.

In our opinion, the presented materials of the article will help to better understand the significance and comprehensiveness of the teaching profession, provide some guidelines for further improvement of professional training of future physical education teachers, which will ultimately help to solve the problem of training animators in Ukraine.

\section{REFERENCES}

[1] N. M. Flehontova. Pedagogical organization of cultural leisure of schoolchildren. Kyiv: Education of Ukraine; 2007.

[2] N. I. Stepanchenko. System of professional training of future teachers of physical education in higher educational institutions: dis. Dr. Ped. Science. Vinnytsia: Vinnytsia State Pedagogical University named after Mykhailo Kotsyubynsky; 2017. Online available from http://repositor y.ldufk.edu.ua/bitstream/34606048/17525/1/Stepanchenko_ N_I\%20.pdf

[3] Khusnul Basriyah , Dwi Sulisworo , Guntur Maruto , Moh Toifur, Nurul Huda Abd Rahman , "Effects of the Flipped Classroom on Understanding the Thermodynamic Concept at High School Students," Universal Journal of Educational Research, Vol. 8, No. 3B, pp. 51 - 58, 2020. DOI: 10.13189/ujer.2020.081506.

[4] S. U. Honcharenko. Ukrainian pedagogical dictionary. Kyiv: Lybid; 1997.

[5] L. V. Kurylo. Theory and practice of animation. Moscow: Soviet sport; 2006.

[6] I. O. Petrova. Leisure in foreign countries. Kyiv: Condor; 2015.

[7] G. A. Avanesova. Cultural and leisure activities: Theory and practice of organization. Moscow: Aspect Press; 2006.

[8] V. Mozgovyi. Pedagogical Animation: Educational Practices of Ukraine and Poland. Comparative professional pedagogy, 9(2), 7-12, 2019. Online available from https://www.khnu.km.ua/root/files/02/20192/3.pdf

[9] Yu. V. Vozna. Social and cultural animation in the context of social and pedagogical activities. Collection of scientific works of Kamyanets-Podilsky National University named after Ivan Ohiyenko. Series: Social and pedagogical, Vol. 25, 24-33, 2015. Online available from http://nbuv.gov.ua/UJR N/znpkp_sp_2015_25_5

[10] A. V. Vindyuk, A. G. Zakharina, E. A. Zakharina. Organization of sports animation. Zaporizhia: CPU; 2014. Online available from http://eir.zntu.edu.ua/bitstream/1234 56789/1937/1/Vindyuk_Organization_of_sporting.pdf

[11] A. V. Sydoruk. Animation activities in the training of future specialists in physical education of secondary schools. Human dimension of harmonization of cultural and educational space of future teachers: scientific achievements and prospects. Melitopol State Pedagogical University named after Bohdan Khmelnytsky, 2015, pp. 176-178.

[12] M. Furkan Bayar , Murat Kurt, M. Akif Haşıloğlu, "Science and Technology Course in Educational Information Network a Review on Videos," Universal Journal of Educational Research, Vol. 6, No. 3, pp. 413 - 420, 2018. DOI: 10.13189/ujer.2018.060308.

[13] L. P. Sushchenko. Theoretical and methodological principles of professional training of future specialists in physical education and sports in higher educational institutions: dis. Dr. Ped. Science. Kyiv: Institute of Pedagogy and Psychology of Vocational Education of the Academy of Pedagogical Sciences of Ukraine; 2003.

[14] O. V. Tymoshenko. Theoretical and methodological principles of optimization of professional training of physical education teachers in higher educational institutions: author's ref. dis. Dr. Ped. Science. Kyiv: M. P. Drahomanov National Pedagogical University; 2009. Online available from http://enpuir.npu.edu.ua/handle/123456789/224

[15] A. V. Sydoruk, N. V. Makovetska. Analysis of the state of preparation of future specialists in physical education for animation activities. Science and Education a New Dimension. Pedagogy and Psychology. Budapest, 2015, Vol. III (28), № 55, pp. 49-53.

[16] V. I. Naumchuk. Animation activities as part of the training of future physical education teachers. Collection of scientific works of Kherson State University. Pedagogical sciences, Vol. 69 (2), pp. 104-108. 2016. Online available from http://nbuv.gov.ua/UJRN/znppn_2016_69(2)_24. 
[17] V. Naumchuk. Model of Professional Training of Future Teachers of Physical Culture in The Process of Self-Working in Sports Games. International Journal of Applied Exercise Physiology, Vol. 8, No 3.1, pp. 35-41, 2019. Doi: 10.26655/IJAEP.2019.10.1

[18] L. I. Danylenko. Innovative educational management. Kyiv: Hlavnyk; 2006.

[19] V. K. Horkavyy, V. V. Yarova. Mathematical statistics. Kyiv: Professional; 2004.

[20] J. Dumazedier. On the way to a civilization of leisure. $M S U$ Journal, № 1, pp. 83-86, 1993.

[21] E. B. Mambekov. Organization of leisure in France: Animation model: author's ref. dis. PhD. St. Petersburg: State Institute of Culture, 1992. Online available from http://nauka-pedagogika.com/viewer/546157/a?\#?page=12

[22] Yu. A. Streltsov. Culturology of leisure. Moscow: MGUKI; 2003.

[23] V. S. Plotnikova. Basics of animation activities. Petrozavodsk: PetrSU Publishing House; 2015.

[24] E. M. Priezheva. Social and cultural animation in tourism. Moscow: Tourist; 2003.

[25] P. Tadeu, A. Lopes. The game and sociocultural animation A strategy of inclusion and prevention, 2015. Online available from https://www.researchgate.net/publication/29 7766474

[26] M. V. Karchenkova. Pedagogical conditions of formation of readiness of future teachers of physical education for professional activity: author's ref. dis. PhD. Kyiv: M. P. Drahomanov National Pedagogical University; 2006. Online available from http://repository.ldufk.edu.ua/handle/346060 48/10200
[27] L. M. Kravtsova. Development of readiness of the future teacher of physical education for extracurricular activities with schoolchildren: author's ref. dis. PhD. Chelyabinsk: Ural State University of Physical Culture; 2010. Online available fromhttps://www.dissercat.com/content/razvitie-g otovnosti-budushchego-uchitelya-fizicheskoi-kultury-k-vne urochnoi-deyatelnosti-so-

[28] O. A. Ayashev. Formation of professional readiness of the future teacher for educational work by means of physical education: author's ref. dis. Dr. ped. Science. Moscow: State Central Institute of Physical Culture of the Order of Lenin; 1991. Online available from http://repository.ldufk.edu.ua:8 080/bitstream/34606048/1025/1/ayashev_o_a.pdf

[29] O. V. Petunin. Theoretical bases of preparation of students for professional activity of the teacher of physical culture: extended abstract of doctoral thesis. Moscow: Russian State University of Physical Education, Sport, Youth and Tourism (SCOLIPE); 1993. Online available from http://repository.l dufk.edu.ua/handle/34606048/71

[30] I. M. Asanova, S. O. Deryabina, V. V. Ignatieva. Organization of cultural and leisure activities. Moscow: Academy; 2012.

[31] M. A. Alekseeva. Development of creative potential of students in the course of training in a technique of teaching of special disciplines: dis. $\mathrm{PhD}$ in pedagogical science. Kostroma: Kostroma State University named after N.A. Nekrasov; 2002

[32] H. V. Belenka, N. I. Bohdanets-Biloskalenko, O. L. Bohinich, Yu. O. Volynets, O. V. Kovalenko, A. V. Kyshynska, M. A. Mashovets, N. I. Melnyk, O. A. Polovina. Preparing future educators to work with preschool children: a competency approach. Kyiv: Borys Hrinchenko University of Kyiv Publishing House, 2015. 